Original Research Paper

\title{
DNA Yields and PCR Amplification Success Using Degraded Animal Corpses
}

\author{
${ }^{1}$ Jimmy Ilunga, ${ }^{1,2}$ Paul Michael, ${ }^{1}$ Grace Daniel, ${ }^{1}$ Jean Francois Robitaille and ${ }^{1}$ Frank F. Mallory \\ ${ }^{1}$ Department of Biology, University of Sudbury, Ontario, Canada, P3E 2C6, Canada \\ ${ }^{2}$ Biomolecular Sciences Program, Laurentian University, Sudbury, Ontario, Canada, P3E 2C6, Canada
}

\author{
Article history \\ Received: 10-12-2019 \\ Revised: 17-01-2020 \\ Accepted: 04-02-2020 \\ Corresponding Author: \\ Paul Michael \\ Department of Biology, \\ University of Sudbury, Ontario, \\ Canada, P3E 2C6, Canada and \\ Biomolecular Sciences \\ Program, Laurentian, \\ University, Sudbury, Ontario, \\ Canada, P3E 2C6, Canada \\ Email: pmichael@laurentian.ca
}

\begin{abstract}
A recurring problem with ancient specimens from wildlife animals is that their preserved tissues contain small amounts of DNA in a degraded state. The specific objectives of the present study were: (1) To determine DNA yields from different animal tissues; (2) to compare traditional (manual) DNA extraction protocols with commercial procedures and (3) to assess the success of PCR amplification of Inter-Simple Sequence Repeats (ISSR) loci in degraded animal samples. Liver, stomach and muscle samples were extracted from coyote (Canis latrans) and longtailed weasel (Mustela frenata) for this research. Manual protocols for DNA extraction were compared to a commercial kit procedure (Qiagen DNeasy kit). Genomic DNA in different states (intact, apoptotic and degraded) were amplified using a panel of ISSR primers. No DNA was recovered from coyote stomach samples using the manual extraction protocol. DNA concentrations in stomach and liver samples from coyote were $10.31 \mathrm{ng} / \mu \mathrm{L}$ and $15.8 \mathrm{ng} / \mu \mathrm{L}$, respectively using the Qiagen extraction kit. In general, the kit extraction method yielded more DNA than the manual extraction procedure but it is more expensive. Intact and apoptotic genomic DNA were successfully amplified by PCR resulting in a similar profile. Artificially degraded DNA showed partial amplification. Thus, the ISSR marker system is suitable for animal population genetics when only limited and/or degraded animal DNA is available.
\end{abstract}

Keywords: Animal Corpses, Coyote (Canis latrans), Long-Tailed Weasel (Mustela frenata), DNA Yields and Degradation, PCR Amplifications,

ISSR Analysis

\section{Introduction}

Preserved tissues of ancient specimens of wildlife animals contain small amounts of DNA in a degraded state. It is essential to make this DNA accessible for enzymatic manipulations. This normally involves the use of PCR amplification methods. However, most DNA extraction protocols are suited for fresh tissues containing intact cells and high molecular weight DNA. Virtually no cell structures are preserved in ancient specimens and it may be more difficult to get the DNA in aqueous solution (Geigl, 2002). There are different conditions that can lead to ancient DNA damage leading to a decrease in the ability to gain an accurate DNA profile. To minimize DNA degradation, aggressive treatments including high temperatures and strong detergent should be avoided. These treatments may indeed increase DNA release but would in turn decrease the overall DNA yield by further damaging the ancient DNA molecules (Rohland and Hofreiter, 2007).

DNA yield varies also with the extraction method used. DNA extraction using a commercial kit has been proven efficient for DNA analysis from various types of samples involved in wildlife crimes. Comparative studies have revealed that different kits are uniformly efficient for extracting DNA (Claassen et al., 2013). The increased effectiveness has been attributed to the proprietary chemicals provided in the kits, such as modified DNA polymerases and buffers. On the other hand, the commercial kits have been found to be quite expensive, limiting their extensive adoption in several countries where wildlife crimes often occur.

Extracted DNAs are usually analyzed using PCRbased methods. Advances in molecular biology 
techniques have provided useful tools for forensics, genetics and genetic diversity among many other applications (Paetkau and Strobeck, 1994; Schander and Kenneth, 2003). Preferably, the DNA extraction techniques should be enhanced to obtain the optimal DNA yield and quality for any species or species group; this will therefore enable suitable processing and analysis of genetic variability. DNA analysis is generally carried out using blood, feces and hair samples in genetic studies (Paetkau and Strobeck, 1994). There will be a greater PCR amplification success rate by extracting from blood and muscle tissues in comparison to DNA from sources such as feces and hair, which are noninvasively collected (Proctor et al., 2005). All the same, given the difficulty of handling and trapping rare animals such as bears, wolves, coyotes etc., the non-invasive methods can offer a useful alternative source of DNA. Even though the field sampling of non-invasive samples would require less time, money and field expertise than the collection of invasive samples, it is essential to make certain that the non-invasively collected samples give high quality DNA with good quantity in order to yield precise genotyping results.

Analysis of DNA are estimated by using different molecular marker systems including Restriction Fragment Length Polymorphism (RFLP), Amplified Fragment Length Polymorphism (AFLP), microsatellites (SSR), Single Nucleotide Polymorphism (SNP), InterSimple Sequence Repeats (ISSR) and Random Amplified Polymorphic DNA (RAPD) (Herrera et al., 2003; Bardakci, 2001; Mehes et al., 2007). The level of polymorphism that can be detected varies with the marker system used.

ISSR has been used in several conservation projects. It can be used without knowledge of the sequence information of genomic DNA (Zietkiewicz et al., 1994). In fact, the ISSR marker technique encompasses Polymerase Chain Reaction (PCR) amplification of DNA using a single primer composed of a microsatellite sequence. The ISSR has good reproducibility at a reasonable cost and is easy to use, allowing it to be useful for genetic studies of populations ( $\mathrm{Li}$ and Xia, 2005; Chen et al., 2005). Most molecular analyses of degraded samples use expensive techniques such as mini-STRs, SNPs and other DNA sequencing protocols. There are no reports of application of ISSR to studies of damaged DNA.

The main objectives of the present study are: (1) To determine DNA yields in different animal tissues, (2) to compare traditional (manual) DNA extraction protocols with commercial procedures; and (3) to determine the PCR amplifiability (amplification success) of ISSR loci in degraded animal samples.

We hypothesize that (a) DNA yields will vary with the types of tissues; (b) Manual (traditional) DNA extraction procedures are cost effective compared to commercial kits and (c) Degraded DNA from animal tissues are less amplifiable than intact DNA from fresh samples using a PCR based system.

\section{Materials and Methods}

\section{Animal Samples}

Coyote (Canis latrans) corpses from the Canadian Ministry of Natural Resources in Alberta had been stored at $-80^{\circ} \mathrm{C}$ for over 10 years. Samples were collected from stomach and liver from these preserved tissues from each carcass. Samples of long-tailed weasel (Mustela frenata) corpses were obtained from Dr. J-F. Robitaille's (Laurentian University) laboratory and they had been preserved for a year in a freezer $\left(-20^{\circ} \mathrm{C}\right)$. All the samples were kept at $-20^{\circ} \mathrm{C}$ to prevent enzymatic degradation and decomposition of the DNA until used.

\section{Manual DNA Extraction}

Frozen samples were cut into small pieces directly into a pre-cooled mortar, to which liquid nitrogen had been added. The tissue was ground to a fine powder using a pestle, while continuously adding liquid nitrogen. The resulting fine cold powder was transferred to a disposable $50 \mathrm{~mL}$ centrifuge tube. Nine $\mathrm{ml}$ of prewarmed $\left(55^{\circ} \mathrm{C}\right)$ lysis buffer $(50 \mathrm{mM}$ Tris- $\mathrm{HCl}$ : $\mathrm{pH}$ 8.0, $50 \mathrm{mM}$ EDTA, $1 \% \mathrm{SDS}, 10 \mathrm{mM} \mathrm{NaCl}$ ) was added to the tube and the powder was re-suspended gently. The solution was then digested with $100 \mu \mathrm{L}$ of $10 \mathrm{mg} / \mathrm{ml}$ Proteinase $\mathrm{K}(100 \mu \mathrm{g}$ in solution) to eliminate any traces of proteins. The digestion mixture was incubated in a water bath at $55^{\circ} \mathrm{C}$ for $3 \mathrm{~h}$ and each sample was treated very gently to prevent DNA shearing.

Ten ml of CIA ( 1 part isoamyl alcohol: 23 parts chloroform) was added to the solution. This was mixed carefully for $5 \mathrm{~min}$ and centrifuged at $12,000 \mathrm{rpm}$ for 15 min. The supernatant was delicately removed and dispensed into a new $50 \mathrm{~mL}$ disposable centrifuge tube, while the interphase and bottom layers were discarded. The CIA extraction was repeated three more times.

One $\mathrm{ml}$ of $3 \mathrm{M} \mathrm{NaOAc}$ ( $\mathrm{pH}$. 4.0), 2 volumes of cold ethanol $(100 \%)$ were added to the supernatant and gently mixed. If DNA was visible in the form of a stringed spool, a hooked and sealed Pasteur pipette was used to remove it out of the tube. Otherwise, the tube was centrifuged for $15 \mathrm{~min}$ at $12,000 \mathrm{rpm}$, resulting in a DNA pellet at the bottom of the tube. In the latter case, the cold ethanol was removed without disturbing the pellet. The resulting pelleted DNA was washed with $70 \%$ ethanol. The wash process was repeated before ethanol was removed and the tubes were inverted. The DNA was re-suspended in $250 \mu \mathrm{L}$ of $1 \mathrm{x}$ TE (Tris EDTA). To ensure the removal of all traces of RNA, 10 
$\mu \mathrm{L}$ of $100 \mathrm{ng}$ ribonuclease (Rnase A) was used. The solution was then incubated in a water bath for 30 to 60 min. at $37^{\circ} \mathrm{C}$. Samples that had low DNA yields were also precipitated with isopropanol. The solution was centrifuged at $12000 \mathrm{rpm}$ in an IEC Micromax centrifuge for $15 \mathrm{~min}$. The isopropanol/salt was then removed by inverting the solution into appropriate waste tubes. The remaining pellet though not visible, was washed with $70 \%$ room temperature ethanol. The solution was micro-centrifuged at $6,500 \mathrm{rpm}$ for $30 \mathrm{~min}$. The ethanol was carefully removed and the microcentrifuge tubes were allowed to air dry. The pellet was then re-suspended in $200 \mu \mathrm{L}$ of $1 \mathrm{X}$ TE.

\section{Kit Extraction}

The kit extraction method was carried out for all the samples collected. As with manual extraction, $25 \mathrm{mg}$ of tissue were cut into small pieces and placed in a $1.5 \mathrm{~mL}$, micro-centrifuge tube. About $180 \mu \mathrm{L}$ Buffer ATL and 20 $\mu \mathrm{L}$ proteinase $\mathrm{K}$ were added and the mixture was incubated at $55^{\circ} \mathrm{C}$ until the tissue was completely lysed. This was done while vortexing occasionally during incubation to disperse the samples. This step was followed by an addition of $200 \mu \mathrm{L}$ Buffer AL to the sample that was then mixed thoroughly and incubated at $70^{\circ} \mathrm{C}$ for $10 \mathrm{~min}$. Then $200 \mu \mathrm{L}$ of ethanol $(100 \%)$ was added to the sample and mixed thoroughly by vortexing. Afterwards, the mixture was transferred via pipette to DNeasy spin column and placed in a $2 \mathrm{~mL}$ collection tube before centrifuging at $8000 \mathrm{rpm}$ for $1 \mathrm{~min}$. We placed the DNeasy mini spin column in a new $3 \mathrm{~mL}$ collection tube before adding $500 \mu \mathrm{L}$ Buffer AW1 and centrifuged for $1 \mathrm{~min}$ at $8000 \mathrm{rpm}$. Afterwards, flowthrough and collection tube were discarded. We subsequently placed the DNeasy Mini spin column in a 2 $\mathrm{mL}$ collection tube, added $500 \mu \mathrm{L}$ Buffer AW2 before centrifuging for $3 \mathrm{~min}$ at $14000 \mathrm{rpm}$ to dry the DNeasy membrane. The flow through and collection tube was discarded once again.

The final step was carried out twice and entailed placing the DNeasy Mini spin column into a clean $2 \mathrm{~mL}$ micro-centrifuge tube before pipetting $200 \mu \mathrm{L}$ of Buffer AE directly into the DNeasy membrane. The solution was incubated at room temperature for $1 \mathrm{~min}$ before being centrifuged for $1 \mathrm{~min}$ at $8000 \mathrm{rpm}$ to elute.

\section{DNA Quantification}

The concentration of the extracted genomic DNA was determined by the fluorochrome Hoechst 33258 with the DNA quantification kit from Bio-Rad (catalogue \#170-2480). A series of 96 well micro titer plates were spotted with $200 \mu \mathrm{L}$ of Hoechst 33258 dye mixture prepared using the fluorescence DNA quantification kit (Bio-rad). The mixture was composed of $18 \mathrm{~mL}$ of double distilled water $\left(\mathrm{ddH}_{2} \mathrm{O}\right), 2 \mathrm{~mL} 10 \mathrm{x}$ tris-EDTA $\mathrm{NaCl}$ (TEN) buffer and $4 \mu \mathrm{L}$ Hoechst 33258 $10 \mathrm{mg} / \mathrm{mL}$ dye. DNA concentration was determined by generating a standard curve by adding in duplicate a known standard concentration of calf thymus DNA to the micro titer plate in an amount that varied from 17,500 ng to a minimum of $25 \mathrm{ng}$. DNA was added to the plate in duplicate in $2 \mu \mathrm{L}$ aliquots. The DNA fluorescence intensity was measured using a BMG LABTECH FLUORstar OPTIMA micro plate multi-detection reader in fluorescence detection mode. DNA samples were further standardized to a concentration of $5 \mathrm{ng} / \mu \mathrm{L}$ for PCR amplification. Statistical differences between DNA yields were determined using the Student T test.

\section{Amplification with ISSR Primers}

Intact genomic DNA and artificially degraded DNA (by boiling) from $M$. frenata were compared for PCR amplification. DNA samples with advanced apoptosis were also used. A total of 7 ISSR primers synthesized by Invitrogen were selected for DNA amplification (Table 1). PCR analysis was carried out following the procedure described by Vaillancourt and Nkongolo (2008) and Nkongolo et al. (2014). Each PCR reaction was performed using a total of $25 \mu \mathrm{L}$ volume containing 11.4 $\mu \mathrm{L}$ double distilled water, $10 \mathrm{mM}$ tris- $\mathrm{HCl} \mathrm{pH} 8.3$ at $25^{\circ} \mathrm{C}$ taq buffer, $2 \mathrm{mM} \mathrm{MgSO}_{4}$ and $0.5 \mu \mathrm{M}$ of each dNTP (Applied Biosystems, Foster City, CA), $0.5 \mu \mathrm{M}$ primer, $5 \mathrm{ng} / \mu \mathrm{L}$ genomic DNA and $0.625 \mathrm{U}$ of taq DNA polymerase (Applied Biosystems, Foster City, CA). For each primer, double distilled water was used as a negative control. Also a drop of mineral oil was added to each reaction to prevent evaporation. The samples were amplified in a thermal cycler (Perkin Elmer, Foster City, $\mathrm{CA})$. The cycles performed were as follows: An initial denaturation at $95^{\circ} \mathrm{C}$ for $5 \mathrm{~min}$, followed by a $2 \mathrm{~min}$ incubation at $85^{\circ} \mathrm{C}$ at which point the taq polymerase was added; 42 cycles of $30 \mathrm{sec}$ at $95^{\circ} \mathrm{C}, 90 \mathrm{sec}$ at $55^{\circ} \mathrm{C}$ and $30 \mathrm{sec}$ at $72^{\circ} \mathrm{C}$; a final extension for $7 \mathrm{~min}$ at $72^{\circ} \mathrm{C}$ was followed by subsequent incubation at $4^{\circ} \mathrm{C}$.

Table 1: ISSR primers, their sequences and the size of the fragments amplified. From Mustela frenata muscle samples

\begin{tabular}{|c|c|c|}
\hline ISSR Primer & $\begin{array}{l}\text { Nucleotide } \\
\text { sequence }\left(5^{\prime}-3{ }^{\prime}\right)\end{array}$ & $\begin{array}{l}\text { Fragment } \\
\text { size range (bp) }\end{array}$ \\
\hline 809 & $(\mathrm{AG}) 8 \mathrm{G}$ & $250-850$ \\
\hline 823 & (TC)8C & - \\
\hline 835 & $(\mathrm{AG}) 8 \mathrm{YC}$ & $200-1000$ \\
\hline 873 & $(\mathrm{GACA}) 4$ & - \\
\hline НB17898B & (CA)6GT & $200-1650$ \\
\hline HB 15 & (GTG)3GC & $200-1000$ \\
\hline HB 17989 A & (CA)8GT & $200-1750$ \\
\hline
\end{tabular}


To the PCR product, $5 \mu \mathrm{L}$ of loading buffer was added to make a total of $30 \mu \mathrm{L}$. About half of this volume was loaded in a $2 \%$ agarose gel stained with $1 \mu \mathrm{L}$ ethidium bromide. Running buffers used were $0.5 \mathrm{X}$ tris borate EDTA or $1 \mathrm{X}$ tris acetate EDTA buffer. These products were run against a $1 \mathrm{~kb}$ plus DNA ladder for approximately $150 \mathrm{~min}$ at 64 volts. The agarose gels were visualized and documented by using the Bio-Rad ChemiDoc XRS system and analyzed with the discovery series quantity $1 \mathrm{D}$ Analysis software. Each assay was repeated three times.

\section{Results}

\section{DNA Quality Test}

All the genomic DNA samples were tested to assess their degradation level (Fig. 1 to 3). They were run in a $1 \%$ agarose gel with $0.5 \%$ Tris-Borate-EDTA (TBE) buffer. Intact DNA appeared as a tight band of high molecular weight (Fig. 2) and degraded DNA as a smear (Fig. 1b). Apoptotic DNA appeared essentially as laddered segments (Fig. 3).

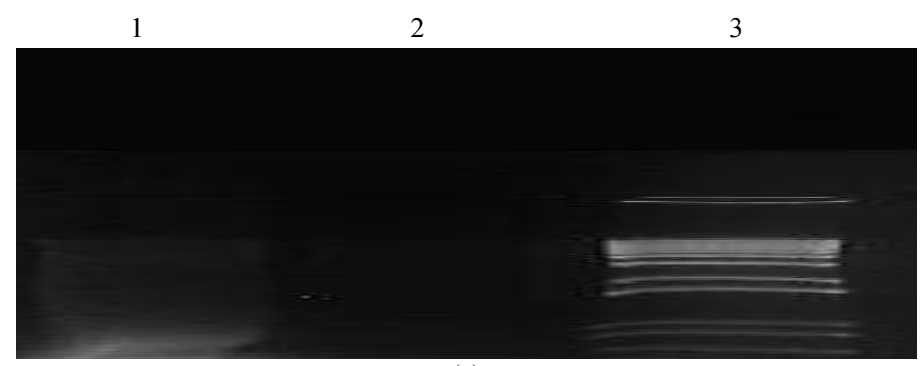

(a)

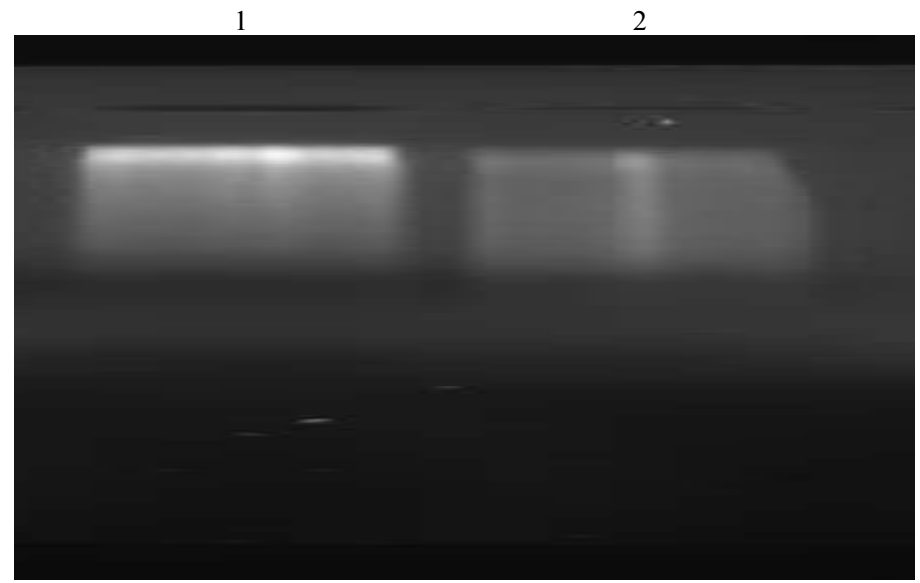

(b)

Fig. 1: (a) DNA yield in coyote (Canis latrans) stomach using standard procedure. Lanes 1 and 2 contain extracted DNA and lane 3 DNA ladder and (b) DNA yield in coyote stomach Qiagen Kit. Note the absence of DNA in coyote stomach following a manual extraction protocol (a) and the DNA presence following a kit extraction procedure

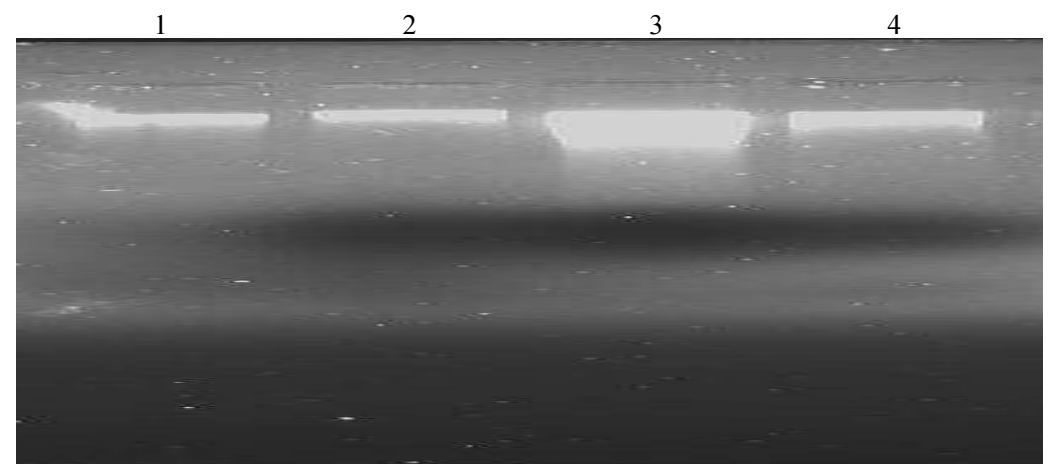

Fig. 2: DNA extracted from coyote liver tissue using Qiagen kit; Lanes 1 to 4 contains DNA from coyote (Canis latrans) liver tissue samples. Note the strong bands showing intact DNA 


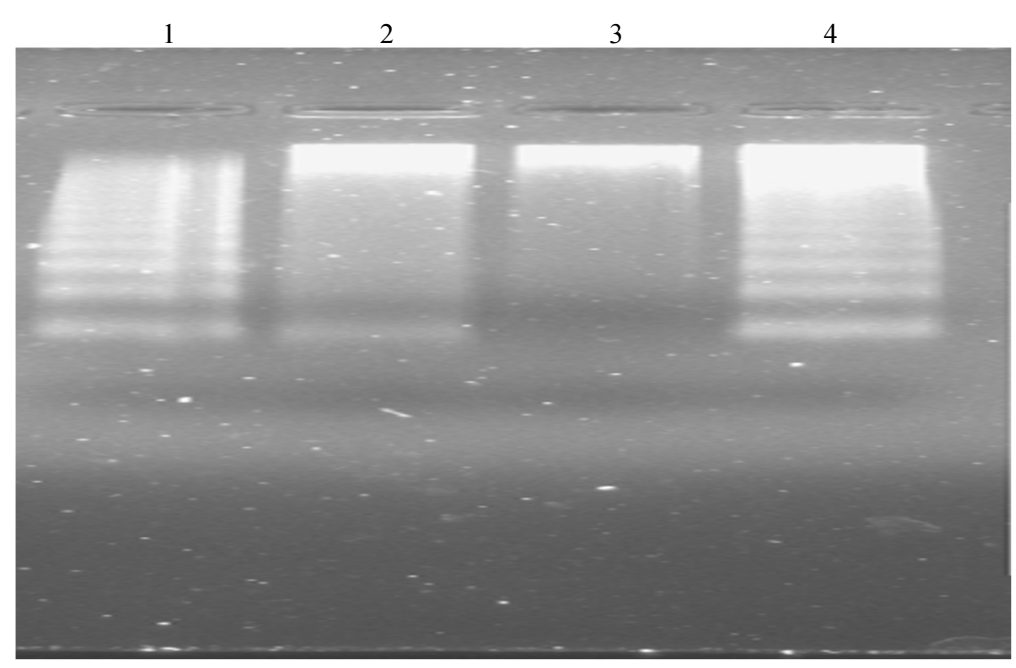

Fig. 3: DNA extracted from Mustela frenata masseter muscle using Qiagen kit. Samples 1 and 4 show Fragmented DNA resulting from apoptosis and lanes 2 and 3 show partially degraded DNA samples. Note that the laddering of DNA samples

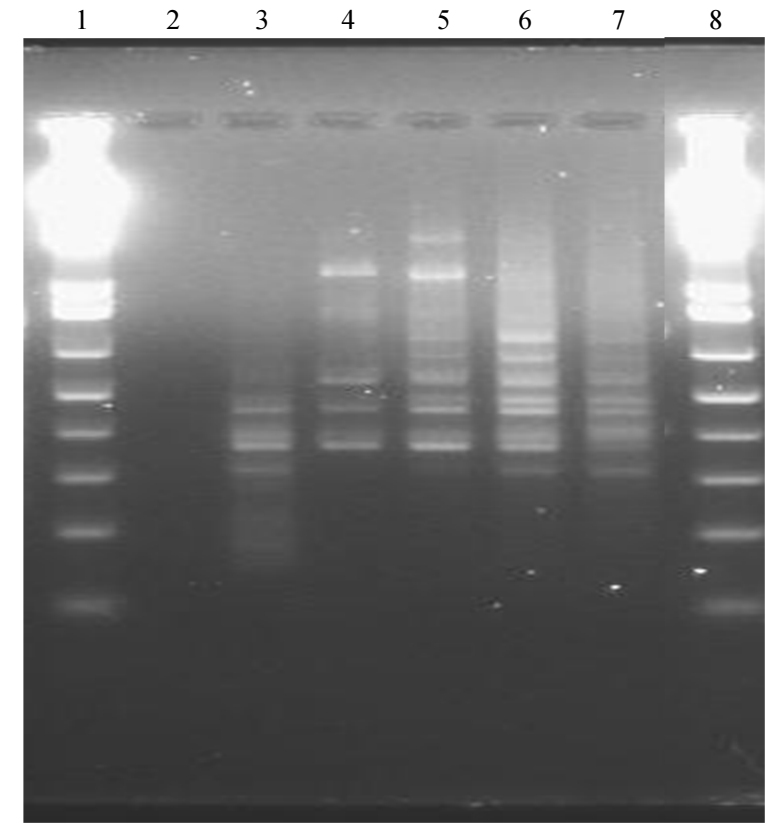

Fig. 4: PCR amplified DNA products from Mustela frenata muscle samples using ISSR primers; PCR Primers HB 17989 A were used for the PCR mix; Lanes 1 and 8 contain DNA ladder; lanes 2 and 3 contain amplified products from boiled degraded DNA; lanes 4 and 5 amplified products from intact DNA (not degraded); and lanes 6 and 7 amplified products from fragmented DNA

\section{DNA Yields}

The results of DNA extraction using manual extraction and a commercial kit were compared (Fig. 1). Measurable amount of genomic DNAs were extracted from all the samples using a commercial kit. In fact, no detectable genomic DNA was extracted from long term preserved stomach samples using manual procedures, while 10.31 $\mathrm{ng} / \mu \mathrm{L}$ of DNA were isolated from the same tissue using the Qiagen extraction kit. Overall, manual extraction was cost effective (less than $\$ 1 /$ sample) compared to the commercial kit procedure ( $\$ 8 /$ sample), when the samples were not too degraded.

There was significantly more DNA in liver compared to stomach in coyote corpses preserved under the same conditions for over 10 years. In fact, DNA yield in stomach and liver samples were 10.31 and $15.76 \mathrm{ng} / \mu \mathrm{L}$, respectively following the kit extraction protocol. Extraction of $M$. frenata muscle samples with the Qiagen kit resulted in a $15.4 \mu \mathrm{g} / \mu \mathrm{L}$ of DNA. Some of these samples revealed the presence of apoptosis (DNA laddering) (Fig 3). DNA laddering was confirmed by extracting DNA from a lysed cell homogenate followed by agarose gel electrophoresis.

\section{DNA Amplification}

\section{ISSR Amplification}

Apoptotic cells were not observed in coyote tissues. DNA laddering, the main characteristic of apoptosis was observed in some samples of M. frenata. M. Frenata DNA degraded by boiling in an autoclave was also amplified (Fig. 4). Sizes of the amplified fragments are described in Table 1. Four of the ISSR primers amplified all the DNA samples including intact genomic DNA, degraded genomic DNA and laddering DNA from apoptotic cells (Figs. 4 and 5). PCR amplification indicated that the quality of DNA for most samples is suitable enough to allow PCR amplification of desired fragment length without further purification. In fact, amplified products were produced from all the samples in spite of degradation. Amplification of intact and fragmented DNA resulted in readily visible bands compared to boiled DNA (Figs 4 and 5). 


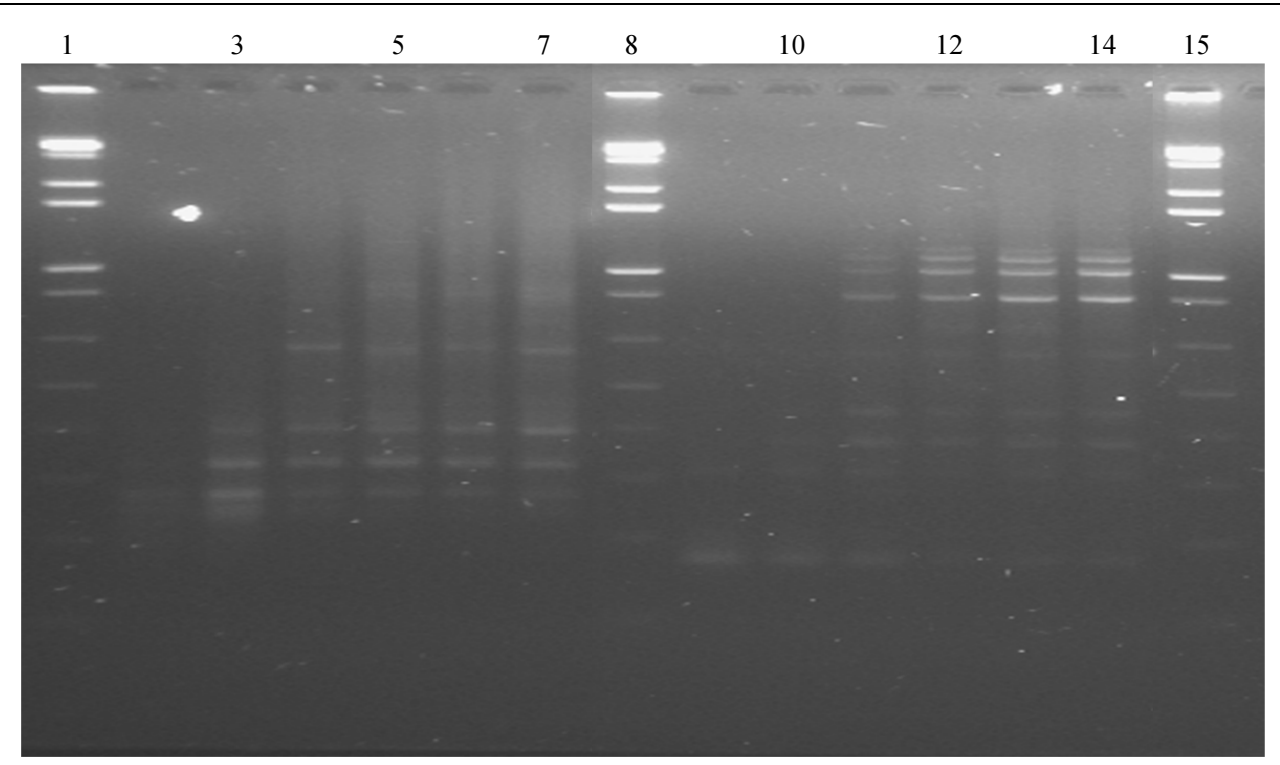

Fig. 5: PCR ISSR of Mustela frenata muscle samples. PCR amplified DNA products using primer HB 835. Lanes 1 and 8 contain DNA ladders; lanes 2 and 3 contain amplified products from boiled degraded DNA; lanes 4 and 5 contain amplified products from intact DNA; lanes 6 and 7 contain amplified products from fragmented DNA. PCR amplified DNA products using primer HB 17989 B. Lanes 9 and 10 contains amplified products from boiled degraded DNA; lanes 11 and 12 amplified products from intact DNA; and lanes 13 and 14 contain amplified products from fragmented DNA. Lane 15 contains DNA ladder

\section{Discussion}

The agarose gel concentration and choice of buffer used during this study was based on the resolution. For higher molecular weight DNA molecule resolution, $1 \%$ agarose gel (larger pore) and Tris-acetate EDTA buffer was utilized (Miura et al., 1999). For better resolution of smaller DNA bands, a higher percentage agarose gel (2\%) in combination with tris-borate EDTA buffer has been shown to be the preferred choices (Miura et al., 1999).

DNA quantification was achieved by using Hoechst dye 33258. A compound that binds preferably to $\mathrm{A} / \mathrm{T}$ pairs in double stranded DNA (Labarca and Piagen, 1980). Its selective binding to double stranded DNA offers an advantage to other techniques as it prevents contaminants from other molecules such as RNA and phenol used during DNA extraction from contributing to the reading. This assay can also detect DNA concentration as low as $8 \mathrm{ng} / \mu \mathrm{L}$.

\section{Comparison Between Tissues}

All the genomic DNA samples were tested to assess their degradation level. It is established that all sources of DNA will degrade given enough time and exposure to the environment and this process of degradation can be the results of a combination of several factors.

In the present study, genomic DNAs were extracted from stomach, liver and muscle tissues. Successful extraction of DNA depends strongly to the types of the tissues and the conditions of the specimens. Janjua et al. (2014) obtained the greatest average DNA quantity and purity from blood samples regardless of the extraction method used compared to muscle, hair and fecal samples. In the present study, the successful extraction of DNA depicted by the intact DNA band without shearing showed that the manual extraction method can work effectively depending on the state of the sample and the tissue.

Commercial kits provide a simple and convenient way to isolate pure genomic DNA of a high-quality. This is consistent with Schill and Steinbruck (2007) who reported when comparing different protocols for DNA extraction and PCR amplification of mitochondria genes of tardigrades. However, when analyzing large populations, the manual extraction is cost effective. For example, in the present study it cost 9 fold more to extract DNA with the Qiagen kit compared to manual extraction. But extracting DNA with a commercial kit was a more efficient technique regardless of the types of the tissues. In fact, DNA could not be extracted using the manual method but the kit based extraction worked fine. The two methods use different reagents and processes. The commercial kit uses a silica column resulting in high yield and purity with less contaminants in the extracted DNA while the manual method is based on phenolchloroform extraction.

When comparing tissues via the kit extraction method, the DNA yields in liver samples were significantly higher than stomach samples. The variability in DNA quality and purity can be described by tissue specific structural complexity. Liver, kidney and brain tissues comprise of delicate membrane cells with few fibrous cells. However, the skin contains 
stratified tissue with keratin and other fibrous cells. Muscle tissue is comprised of many proteins within the cell. Adipose tissue consists mainly of lipids, which increase cell volume and decrease cell number. In addition, lipid is water insoluble, which hinders extraction, lysing a smaller number of nuclei (Junqueira and Carneiro, 1995).

The extraction of the $M$. frenata muscle samples retrieved fragmented DNA suggesting apoptosis. The presence of apoptosis was inferred by DNA laddering observed in some samples. The extraction of DNA from a lysed cell homogenate followed by agarose gel electrophoresis is an efficient and easy method of confirming DNA laddering. In fact, we visualized the endonuclease cleavage products typical of apoptosis as described by Wyllie (1980). These results were characteristic of "DNA ladder" with each band in the ladder separated in size by approximately 180 base pairs. This methodology is easy to perform, has a sensitivity of $1 \times 10^{6}$ cells (i.e., level of detection is as few as 1,000,000 cells) and is useful for tissues and cell cultures with high numbers of apoptotic cells per tissue mass or volume, respectively. The presence of DNA laddering suggests that the tissues were at the later phase of apoptosis (Wyllie, 1980).

Apoptosis or programmed cell death is indeed a genetically determined process of cell self-destruction that is marked by the fragmentation of nuclear DNA. It is a normal physiological process eliminating damaged DNA and superfluous or unwanted cells (Liao, 2005).

Because billions of cells die every day in their bodies, animals have evolutionarily developed apoptosis to preserve the tissue environment from adverse effects of dead cells, a process achieved via phagocytosis of the cell corpses by phagocytes that are collectively referred to as scavengers (Liu et al., 2013).

The alternative to apoptotic cell death is necrosis, which is considered to be a toxic process where the cell is a passive victim and follows an energy-independent mode of death. But since necrosis refers to the degradative process that occurs after cell death, it is considered by some to be an inappropriate term to describe a mechanism of cell death (Majno and Joris, 1995; Levin et al., 1999).

\section{ISSR Analysis}

Polymerase chain reaction was used to analyze the amplification success of DNA of different degradation conditions using ISSR marker system. PCR reliability, feasibility and precession depends on the high quality genomic DNA with low level of fragmentation. In the present study four ISSR primers amplified all the DNA samples including intact genomic DNA, degraded genomic DNA and laddering DNA from apoptotic cells. Hence, the ISSR marker system can be used in forensic cases or in applications involving degraded samples. This molecular system is a reliable technology that can be used to differentiate closely related individuals (Godwin et al., 1997; Mehes et al., 2007; Moarefi et al., 2018; Boyd et al., 2019). This marker system has been successfully applied to genetic analysis of plants and animals. ISSR marker system accesses variation in the numerous micro-satellite regions dispersed throughout the genome (Semagn et al., 2006) and circumvents the challenge of characterizing individual loci that other molecular approaches require.

The ISSR method provides an alternative choice to other systems for obtaining highly reproducible markers without any necessity for prior sequence information for various genetic analyses. The ISSR method takes advantage of the ubiquitously distributed SSRs in the eukaryotic genomes. Because of those abundant and rapidly evolving SSR regions, ISSR amplification has the potential of revealing larger numbers of polymorphic fragments per primer than any other marker system used such as RFLP or microsatellite. As the PCR reaction amplifies the sequence between two SSRs, the PCR products generate a profile with multiple loci.

Compared to other arbitrary primers, ISSRs provide great potential to determine intra- and inter - genomic polymorphisms, as they reveal simultaneously variation within unique regions of the genome at several loci. ISSRs are extremely useful markers because they inherit several properties of microsatellite such as high variability among taxa, ubiquitous occurrence and high copy number in eukaryotic genomes (Morgante et al., 1996; Al-Turki and Basahi, 2015; Yeasmin et al., 2015). These markers exhibit specificity of sequence tagged site markers, but need no sequence information for primer synthesis having the advantage over random markers. The multiple profiles generated by ISSR primers are highly polymorphic and as such are ideal for the study of genetic variability (Nkongolo et al., 2005; Stolpovsky et al., 2014; Rainville et al., 2017)

The ISSR marker system offers different advantages compared with other molecular marker such as AFLP and SSR. They include: (1) No prior sequence information required, (2) simple and quick operation, (3) amenable to laboratory level, (4) high stability, (5) abundance of genomic information, (6) use of radioactivity is not required and (7) show high polymorphism (Kurane et al., 2009). Unlike other molecular markers, ISSRs access variation in the numerous microsatellite regions dispersed throughout the various genomes. This facilitates the characterization of individual loci (Semagn et al., 2006; Mehes et al., 2007; Sharma et al., 2008; Kurane et al., 2009; Nkongolo et al., 2014).

There are other advantages associated with the ISSR multi-locus technique. ISSRs are universal in the sense that microsatellite repeats are found in every eukaryotic 
genome studied to date. Longer lengths of primers permits the use of higher annealing temperature, which in turn reduces non-specific binding and results in higher stringency (Bornet and Branchard, 2004; Qian et al., 2001). Finally, because each band corresponds to a specific DNA sequence by two inverted microsatellites and the amplified products usually range from 1002000 bp long, they can be detected by both agarose and/or polyacrylamide gel electrophoresis (Reddy et al., 2002; Nkongolo et al., 2014).

\section{Conclusion and Significance of the Results}

In the present study, there was more DNA in liver compared to stomach in coyote corpses preserved under the same conditions for over 10 years. The extraction kit procedure yielded more DNA than manual extraction procedure, but it is more expensive. Intact and fragmented genomic DNA was successfully amplified by PCR resulting in a similar profile. Artificially degraded DNA showed partial amplification. Hence, the ISSR marker system is suitable for animal population genetics when only partially degraded (fragmented) animal DNA is available. The present study shows that degraded DNA can be extracted from damaged tissues amplified and analyzed using a simple PCR profiling system such as ISSR.

\section{Acknowledgement}

Laurentian University Research Fund (LURF) supported this study. Thanks to Dr. K.K. Nkongolo for assistance with logistics related to the molecular study.

\section{Author's Contributions}

Jimmy Ilunga and Paul Michael: Carried out the experiments and drafted the manuscript.

Grace Daniel: Assisted with molecular analyses and data processing.

Jean Francois Robitaille: Collected Mustela frenata corpse samples and reviewed the manuscript

Frank Mallory: Assisted with the experimental design, coordinated the sampling of Canis latrans corpses and reviewed the manuscript.

\section{Conflicts of Interest}

The authors declare that they have no competing interests.

\section{References}

Al-Turki, T.A. and M.A. Basahi, 2015. Assessment of ISSR based molecular genetic diversity of Hassawi rice in Saudi Arabia. Saudi J. Biol. Sci., 22: 591-599. DOI: $10.1016 /$ j.sjbs.2015.06.027
Bardakci, F., 2001. Random Amplified Polymorphic DNA (RAPD) markers. Turk J. Bio., 25: 185-196.

Bornet, B. and M. Branchar, 2004. Use of ISSR fingerprints to detect micro satellites and genetic diversity several related Brassica Taxa and Arabidopsis thaliana. Hereditas, 140: 245-248. DOI: $10.1111 /$ j.1601-5223.2004.01737.x

Boyd, M., M.A. Panoyan, P. Michael and K.K. Nkongolo, 2019. Development and characterization of species-diagnostic ISSR and SCAR DNA markers differentiating red maple (Acer rubrum) and silver maple (A. saccharinum). Genome, 62: 527-535. DOI. 10.1139/gen-2019-0037

Claassen, S., E. du Toit, M. Kaba, C. Moodley and H.J. Zar et al., 2013. A comparison of the efficiency of five different commercial DNA extraction kits for extraction of DNA from faecal samples. J. Microbiol. Meth., 94: 103-110.

DOI: 10.1016/j.mimet.2013.05.008

Chen, J.M., X. Liu, J.Y. Wang, R.W. Gituru and Q.F. Wang, 2005. Genetic variation within the endangered quillwort, Isoetës hypsophila (Isoëtaceae) in China as evidenced by ISSR analysis. Aquatic Bot., 82: 89-98.

DOI: $10.1016 /$ j.aquabot.2005.02.007

Geigl, E.M., 2002. On the circumstances surrounding the preservation and analysis of very old DNA. Archaeometry, 44: 337-342. DOI: $10.1111 / 1475-4754 . t 01-1-00066$

Godwin, I.D., E.A. Aitke and L.W. Smith, 1997. Application of Inter Simple Sequence Repeat (ISSR) markers to plant genetics. Electrophoresis, 18: 1524-1528. DOI: 10.1002/elps.1150180906.

Herrera, R., V. Cares, M.J. Wilkinson and P.D.S. Caligari, 2002. Characterization of genetic variation between Vitis vinifera cultivars from Chile using RAPD and ISSR markers. Euphytica, 124: 139-336.

Janjua, S., M. Shahid, F. Abbas and A. Mian, 2014. DNA extraction protocols for molecular studies of Asiatic black bears. Ursus, 25: 78-81.

Junqueira, L.C. and J. Carneiro, 1995. Histologia Básica. 1st Edn., Guanabara Koogan S.A, Rio de Janeiro, pp: 512 .

Kurane, J., V. Shinde and A. Harsulkar, 2009. Application of ISSR marker in pharmacognosy: Current update. Phcog. Rev., 3: 216-228.

Labarca C. and K. Piagen, 1980. A simple, rapid and sensitive DNA assay procedure. Anal. Biochem., 102: 344-352.

Levin, S., T.J. Bucci, S.M. Cohen, A.S. Fix and J.F. Hardisty et al., 1999. The nomenclature of cell death: recommendations of an ad hoc committee of the society of toxicologic pathologists. Toxicol. Pathol., 27: 484-490.

DOI: $10.1177 / 019262339902700419$ 
Li, F. and N. Xia, 2005. Population structure and genetic diversity of an endangered species, Glyptostrobus pensilis (Cupressaceae) Bot. Bull. Acad. Sin., 46: 155-162.

Liao, D.J., 2005. The scavenger cell hypothesis of apoptosis: apoptosis redefined as a process by which a cell in living tissue is destroyed by phagocytosis. Med. Hypotheses, 65: 23-28. DOI: 10.1016/j.mehy.2005.01.028

Liu, B., N. Xu, Y. Man, H. Shen and I. Avital et al., 2013. Apoptosis in living animals is assisted by scavenger cells and thus may not many go through cytochrome C-caspase pathway. Cancer, 4: 716-723. DOI: $10.7150 /$ jca. 7577

Majno, G. and I. Joris, 1995. Apoptosis, oncosis and necrosis. An overview of cell death. Am. J. Pathol., 146: 3-15.

Mehes, M.S., K.K. Nkongolo and P. Michael, 2007. Genetic analysis of Pinus strobus and Pinus monticola populations from Canada using ISSR and RAPD markers: Development of genome specific SCAR markers. Plant Syst. Evol., 267: 47-63. DOI: $10.1007 / \mathrm{s} 00606-007-0534-1$

Moarefi, N.P., P. Michael, P. Beckett and K.K. Nkongolo, 2018. Identification of molecular markers differentiating Betula papyrifera and $B$. pumila populations from Northern Ontario (Canada). Am. J. Environ. Sci., 14: 246-256. DOI: 10.3844 /ajessp.2018.246.256

Morgante, M., A. Pfeiffer, A. Costacurta and A.M. Oliviero, 1996. Molecular tools in population and ecological genetics in coniferous trees. Phyton, 36: 129-138.

Miura, Y., H. Wake and T. Kato, 1999. TBE or not $\mathrm{TBE}$; that is the question: Beneficial usage of trisborate for obtaining higher resolution of small fragments by agarose gel electrophoresis. Nagoya Med. J., 43: 1-6.

Nkongolo, K.K., S. Gervais, P. Michael and Y. Zhou, 2014. Comparative analysis of inter simple sequence repeat (ISSR) and Simple Sequence Repeats (SSRs) markers: Genetic analysis of Deschampsia cespitosa populations growing in metal contaminated regions in Canada. Am. J. Biochem. Biotechnol., 10: 69-80. DOI: 10.3844/ajbbsp.2014.69.80

Nkongolo, K.K., P. Michael and T. Demers, 2005. Application of ISSR, RAPD and cytological markers to the certification of Picea mariana, P. glauca and $P$. engelmannii trees and their putative hybrids. Genome, 48: 302-211. DOI: 10.1139/g04-118

Paetkau, D. and C. Strobeck, 1994. Microsatellite analysis of genetic variation in black bear populations. Mol. Ecol., 3: 489-495.

DOI: 10.1111/j.1365-294X.1994.tb00127.x
Proctor, M., B.N. McLellan, C. Strobeck and R. Barclay, 2005. Genetic analysis reveals demographic fragmentation of grizzly bears yielding vulnerably small populations. Proc. Royal Society, 272: 2409-2416.

DOI: $10.1098 / \mathrm{rspb} .2005 .3246$

Qian, W., S. Ge and D.Y. Hong, 2001. Genetic variation within and among populations of a wild rice Oryza granulata from China detected by RAPD and ISSR. Theor. Applied Genet., 102: 440-449.

DOI: $10.1007 / \mathrm{s} 001220051665$

Rainville, S., P. Beckett and K.K. Nkongolo, 2017. Reassessment of molecular variation in isolated populations of Deschampsia cespitosa from metal contaminated regions in Northern Ontario (Canada) after a long period of genetic recombination. Am. J. Environ. Sci., 13: 289-296. DOI: $10.3844 /$ ajessp.2017.289.296

Reddy, M.P., N. Sarla and E.A. Siddiq, 2002. Inter Simple Sequence Repeat (ISSR) polymorphism and its application in plant breeding. Euphytica, 128: 9-17. DOI: 10.1023/A:1020691618797

Rohland, N. and M. Hofreiter, 2007. Comparison and optimization of ancient DNA extraction. Biotechniques, 42: 343-352. DOI: $10.2144 / 000112383$

Schander, C. and H.M. Kenneth, 2003. DNA, PCR and formalized animal tissue-a short review and protocols. Org. Divers. Evol., 3: 195-205. DOI: $10.1078 / 1439-6092-00071$

Schill, R.O. and G.H. Steinbruck, 2007. Identification and differentioan of Heterotardigrada and Eutardigrada species by riboprinting. J. Zool. Syst. Evol. Res., 45: 184-190. DOI: $10.1111 /$ j.1439-0469.2007.00409.x

Semagn, K., A. Bjornstad and M.N. Ndjiondjop, 2006. An overview of molecular markers methods for plants. African J. Biotechnol., 5: 2540-2568.

Sharma, A., A.G. Namdeo and K.R. Mahadik, 2008. Molecular markers: new prospects in plant genome analysis. Pharmacogn. Rev., 2: 23-34.

Stolpovsky, Y.A., N.V. Kol, A.N. Evsyukov, L.V. Nesteruk and C.M. Dorzhu et al., 2014. Comparative analysis of ISSR markers polymorphism in populations of yak (Bos mutus) and in F1 hybrids between yak and cattle in the Sayan-Altai region]. Genetika, 50: 1163-1176. DOI: $10.1134 / \mathrm{S} 1022795414100135$

Vaillancourt, A. and K.K. Nkongolo, 2008. Identification, characterization and chromosome locations of rye and wheat specific ISSR and SCAR markers useful for breeding purposes. Euphytica, 159: 297-306. DOI: 10.1007/s10681-007-9492-5 
Wyllie, A.H., 1980. Glucocorticoid-induced thymocyte apoptosis is associated with endogenous endonuclease activation. Nature, 284: 555-556. DOI: $10.1038 / 284555 \mathrm{a} 0$

Yeasmin, L., M.N. Ali, S. Gantait and S. Chakraborty, 2015. Bamboo: An overview on its genetic diversity and characterization. Biotech, 5: 1-11. DOI 10.1007/s13205-014-0201-5
Zietkiewicz, E., A. Rafalski and D. Labuda, 1994. Genome fingerprinting by Simple Sequence Repeat (SSR) - anchored polymerase chain reaction amplification. Genomics, 20: 176-183.

DOI: $10.1006 /$ geno.1994.1151 